\title{
Faktor-Faktor yang Berhubungan dengan Kepemilikan Saluran Pembuangan Air Limbah Rumah Tangga
}

\author{
Fera Meliyanti \\ Program Studi S1 Kesehatan Masyarakat STIKES Al-Ma'arif Baturaja \\ Email:fera_meliyanti@yahoo.com
}

\section{ARTICLE INFO}

Article history:

Received 5 April 2018

Revised 15 May 2018

Accepted 17 May 2018

Keyword:

Education

Knowledge

Sewerage

DOI:http://dx.doi.org/10.30604/jika.v3i1.87

A B S T R A C T

Scope of sewerage for Belimbing Village in 2014 was eligible amount to 30,71 percent of 127 families (KK) having Sewers Waste (SPAL), in 2015 amounted to 35,67 percent of the 127 families who have SPAL, and in 2016 amounted to 37,71 percent of the 127 families who have SPAL. Based on the coverage of data, the number of households that have SPAL in Belimbing village is still low. The purpose of this study was to determine the factors associated with the ownership of sewerage households. The research is descriptive analytic research with a cross-sectional design. This study population around the head of the family in the village of Belimbing amounted to 127 households. Samples using total sampling. Place of research conducted in the District Supplied Belimbing Village Ogan Komering Ulu. Data were analyzed by univariate and bivariate analysis. The statistical test using chisquare test. From the results, there was a significant relationship between knowledge with SPAL ownership with p-value 0,000; no significant association of education with SPAL ownership with $p$ value 0,000; there is a significant relationship between the length of working with SPAL ownership with p-value 0,002; there is a significant relationship between earnings by ownership SPAL with p-value of 0,015.
\end{abstract}

(c) 2018, Jurnal Aisyah: Jurnal Ilmu Kesehatan. All rights reserved.

\section{PENDAHULUAN}

Melalui keputusan Menteri Kesehatan (Kepmenkes) nomor: 852/ Menkes/ SK/ IX/2008 yang kemudian diperkuat menjadi Peraturan Menteri Kesehatan (Permenkes) Nomor 3 tahun 2014, Sanitasi Total Berbasis Masyarakat (STBM) dikukuhkan sebagai strategi nasional pembangunan sanitasi di Indonesia. STBM merupakan sebuah pendekatan untuk mengubah perilaku higienis dan sanitasi melalui pemberdayaan masyarakat dengan metode pemicuan. Untuk dapat mencapai tujuan tersebut, strategi penyelenggaraan STBM fokus pada penciptaan lingkungan yang kondusif (enabling environment), peningkatan kebutuhan sanitasi (demand creation) serta peningkatan penyediaan akses sanitasi (supply improvement) (Kementerian Kesehatan, 2014). 
Pada umumnya limbah rumah tangga di Indonesia membuang limbahnya langsung ke got $(46,7$ persen $)$ dan tanpa penampungan (17,2 persen). Hanya 15,5 persen yang menggunakan penampungan tertutup di pekarangan dengan dilengkapi SPAL (saluran pembuangan air limbah), 13,2 persen menggunakan penampungan terbuka di pekarangan, dan 7,4 persen penampungannya di luar pekarangan (Riskesdas, 2013).

Akses pelayanan pengolahan air limbah tahun 2014 sebesar 62 persen. Menurut tempat tinggal persentase rumah yang memiliki saluran pembuangan air limbah lebih tinggi di perkotaan sebesar 77,15 persen, dibandingkan dengan persentase rumah tangga yang memiliki saluran pembuangan air limbah di daerah pedesaan sebesar 44,74 persen (Kemenkes RI, 2014).

Puskesmas Lubuk Rukam memiliki wilayah kerja di 7 desa, berdasarkan hasil laporan tahunan tentang data saluran pembuangan air limbah pada tahun 2014, jumlah SPAL yang memenuhi syarat sebesar 45,83 persen, tahun 2015 jumlah SPAL yang memenuhi syarat sebesar 55,79 persen, dan pada tahun 2016 jumlah SPAL yang memenuhi syarat sebesar 60,23 persen (Dinas Kesehatan OKU, 2017).

Cakupan program SPAL untuk Desa Belimbing pada tahun 2014, jumlah SPAL yang memenuhi syarat berjumlah 30,71 persen dari $127 \mathrm{KK}$ yang memiliki SPAL, pada tahun 2015 jumlah SPAL yang memenuhi syarat berjumlah 35,67 persen dari $127 \mathrm{KK}$ yang memiliki SPAL, dan pada tahun 2016 jumlah SPAL yang memenuhi syarat berjumlah 37,71 persen dari $127 \mathrm{KK}$ yang memiliki SPAL (UPTD Puskesmas Lubuk Rukam, 2017).

Dari data tersebut dapat dilihat bahwa jumlah SPAL yang memenuhi syarat kesehatan di Desa Belimbing belum optimal. Karakteristik rumah yang terbuat dari kayu dengan bentuk rumah panggung mendukung masyarakat untuk membuang air limbah rumah tangga langsung ke pekarangan rumah yang dapat merusak tanah permukaan, menimbulkan genangan yang akan menjadi sarang perindukan nyamuk, menimbulkan bau serta mengganggu keindahan. Menurut Kepmenkes RI No. 829/MENKES/SK/VII/1999 tentang persyaratan kesehatan perumahan, ketentuan rumah yang memenuhi persyaratan kesehatan dalam pembuangan limbah yaitu limbah cair yang berasal dari rumah tangga tidak mencemari sumber air, tidak menimbulkan bau, dan tidak mencemari permukaan tanah sedangkan untuk limbah padat harus dikelola dengan baik agar tidak menimbulkan bau, tidak mencemari permukaan tanah dan air tanah (Kementerian Kesehatan, 2014).

Berdasarkan latar belakang tersebut, maka peneliti tertarik untuk meneliti tentang faktor-faktor yang berhubungan dengan kepemilikan saluran pembuangan air limbah rumah tangga.

\section{METODE}

Penelitian ini merupakan penelitian analitik dengan pendekatan cross sectional. Populasi dalam penelitian ini adalah seluruh kepala keluarga yang ada di Desa Belimbing yang berjumlah $127 \mathrm{KK}$ dan sampel yang digunakan adalah total sampling. Penelitian ini dilaksanakan pada bulan Maret sampai dengan bulan Mei 2017. Lokasi penelitian ini dilakukan di Desa Belimbing Wilayah Kerja UPTD Puskesmas Lubuk Rukam Kecamatan Peninjauan Kabupaten OKU.

Data yang dikumpulkan berasal dari Dinas Kesehatan Kabupaten OKU, UPTD Puskesmas Lubuk Rukam dan Kantor Desa Belimbing Kecamatan Peninjauan OKU yang meliputi gambaran umum lokasi penelitian dan data monografi. Tekhnik pengumpulan data yang dilakukan yaitu dengan menggunakan wawancara dan observasi. 
Instrumen yang digunakan adalah kuisioner dan checklist yang berkaitan dengan karakteristik responden mengenai faktorfaktor yang berhubungan dengan kepemilikan SPAL rumah tangga. Data dianalisis dengan analisis univariat dan bivariat. Analisis univariat untuk melihat distribusi frekuensi dan persentase setiap variabel. Analisis bivariat dengan uji statistik Chi-square.

\section{HASIL DAN PEMBAHASAN}

Tabel 1. Distribusi Frekuensi Responden Kepemilikan SPAL Rumah Tangga, Pengetahuan, Pendidikan dan Lama Bekerja

\begin{tabular}{lcc}
\hline \multicolumn{1}{c}{ Variabel } & Frekuensi & Persentase (\%) \\
\hline Kepemilikan SPAL rumah tangga & & \\
Memenuhi syarat & 50 & 39,4 \\
Tidak memenuhi syarat & 77 & 60,6 \\
\hline Pengetahuan & & \\
$\quad$ Baik & 40 & 31,5 \\
Kurang baik & 87 & 68,5 \\
\hline Pendidikan & & \\
Tinggi & 49 & 38,6 \\
$\quad$ Rendah & 78 & 61,4 \\
\hline Lama bekerja & 51 & \\
Waktu bekerja lama & 76 & 40,2 \\
Waktu bekerja tidak lama & & 59,8 \\
\hline Penghasilan & 53 & \\
Tinggi & 74 & 51,7 \\
Rendah &
\end{tabular}

Tabel 1. menunjukkan bahwa untuk variabel kepemilikan SPAL rumah tangga dikategorikan menjadi dua kategori yaitu SPAL rumah tangga yang memenuhi syarat dan SPAL rumah tangga yang tidak memenuhi syarat. SPAL rumah tangga yang tidak memenuhi syarat lebih besar yaitu sebanyak 77 responden $(60,6$ persen) dibandingkan dengan responden SPAL rumah tangga yang memenuhi syarat yaitu 50 responden $(39,4$ persen $)$.

Untuk variabel pengetahuan responden dikategorikan menjadi dua kategori yaitu baik dan kurang baik. Responden berpengetahuan kurang baik yaitu sebanyak 87 responden (68,5 persen) lebih besar dibandingkan responden berpengetahuan baik yaitu 40 responden (31,5 persen).

Variabel pendidikan responden dikategorikan menjadi dua kategori yaitu tinggi jika pendidikan responden $\geq$ SMA dan rendah jika pendidikan responden < SMA. Responden berpendidikan rendah yaitu sebanyak 78 responden (61,4 persen) lebih besar dibandingkan responden yang berpendidikan tinggi yaitu 49 responden (38,6 persen).

Variabel lama bekerja responden dikategorikan menjadi dua kategori yaitu waktu bekerja lama (PNS, TNI, polri, swasta) dan waktu bekerja tidak lama (buruh, petani). Responden mempunyai waktu bekerja tidak lama yaitu sebanyak 76 responden (59,8 persen) lebih besar dibandingkan waktu bekerja lama yaitu sebanyak 51 responden (40,2 persen).

Variabel penghasilan responden dikategorikan menjadi dua kategori yaitu tinggi jika penghasilan responden $\geq \mathrm{Rp}$ 2.388.000,-/bulan dan rendah jika penghasilan responden $<\mathrm{Rp} 2.388 .000$,/bulan. Responden berpenghasilan rendah yaitu sebanyak 74 responden (58,3 persen) lebih besar dibandingkan responden berpenghasilan tinggi yaitu sebanyak 53 responden ( 41,7 persen). 
Tabel 2. Hubungan Pengetahuan Responden Dengan Kepemilikan SPAL Rumah Tangga

\begin{tabular}{|c|c|c|c|c|c|c|c|}
\hline \multirow{3}{*}{ Pengetahuan } & \multicolumn{4}{|c|}{ Kepemilikan SPAL Rumah Tangga } & \multirow{2}{*}{\multicolumn{2}{|c|}{ Jumlah }} & \multirow{3}{*}{$p$ value } \\
\hline & \multicolumn{2}{|c|}{ Memenuhi syarat } & \multicolumn{2}{|c|}{$\begin{array}{c}\text { Tidak memenuhi } \\
\text { syarat } \\
\end{array}$} & & & \\
\hline & $\mathbf{N}$ & $\%$ & $\mathbf{N}$ & $\%$ & $\mathbf{N}$ & $\%$ & \\
\hline Baik & 26 & 65 & 14 & 35 & 40 & 100 & \\
\hline Kurang Baik & 24 & 27,6 & 63 & 72,4 & 87 & 100 & 0,001 \\
\hline Total & 50 & 39,4 & 77 & 60,6 & 127 & 100 & \\
\hline
\end{tabular}

Berdasarkan tabel 2. dapat dilihat bahwa dari 127 responden proporsi responden dengan SPAL rumah tangga yang memenuhi syarat kesehatan pengetahuan baik yaitu 26 (65 persen) lebih besar dibandingkan dengan proporsi responden dengan SPAL rumah tangga yang memenuhi syarat kesehatan berpengetahuan kurang baik yaitu 24 (27,6 persen). Dari hasil uji Chi square diperoleh p-value 0,000 . Artinya ada hubungan yang bermakna antara pengetahuan responden dengan kepemilikan saluran pembuangan air limbah rumah tangga.

Hasil penelitian ini sejalan dengan penelitian Nurhabibah (2015) di Wilayah Kerja Puskesmas Tapus Pasaman bahwa ada hubungan bermakna antara pengetahuan dengan kepemilikan saluran pembuangan air limbah rumah tangga yang berdasarkan hasil uji statistik diketahui $p$ value 0,003 (Nurhabibah, 2015). Penelitian ini juga sejalan dengan penelitian Hermawati (2012) yang menyatakan bahwa tingkat pengetahuan keluarga masih kurang dalam pengolahan limbah cair rumah tangga di Dusun Bottolampe Kabupaten Barru sebelum dilakukan penyuluhan kesehatan (Hermawati, 2012).

Pengetahuan merupakan proses penginderaan manusia terhadap objek diluarnya melalui indera-indera yang dimilikinya, seperti penglihatan, pendengaran, penciuman, dengan sendirinya pada waktu proses penginderaan ini dalam diri individu terjadi proses perhatian, persepsi dan penghayatan terhadap stimulus atau objek dari luar individu. Pengetahuan atau kognitif merupakan dominan yang sangat penting untuk terbentuknya tindakan seseorang (S, 2003). Pengetahuan sangat mempengaruhi akan pemahaman individu untuk mengetahui manfaat kepemilikan saluran pembuangan air limbah sehingga tidak membuang air limbah sembarangan.

Dari hasil penelitian yang dilakukan di Desa Belimbing diperoleh bahwa terdapat hubungan yang bermakna antara pengetahuan terhadap kepemilikan SPAL rumah tangga. Proporsi responden dengan SPAL rumah tangga yang memenuhi syarat kesehatan tetapi pengetahuan kurang baik masih terdapat 27,6 persen dan proporsi kepemilikan SPAL yang tidak memenuhi syarat dengan pengetahuan kurang baik sebesar 72,4 persen. Kurangnya pengetahuan yang dimiliki responden disebabkan karena minimnya informasi yang mereka dapat tentang sanitasi lingkungan terutama tentang SPAL rumah tangga maupun prinsip pengamanan limbah cair rumah tangga yang menjadi aspek penting dalam sanitasi total berbasis masyarakat. Air limbah yang dibuang sembarangan akan merusak tanah permukaan, adanya genangan yang akan menjadi sarang perindukan nyamuk, lalat maupun vektor lainnya, menimbulkan bau yang tidak sedap, dan dapat mengganggu keindahan. Walaupun terdapat sebagian masyarakat sudah mengetahui informasi tentang pentingnya SPAL yang memenuhi syarat kesehatan, faktor perilaku yang sulit diubah terutama kesadaran masyarakat untuk berperilaku hidup bersih dan sehat menyebabkan kondisi SPAL masih belum terlalu dipedulikan. 
Tabel 3. Hubungan Pendidikan Responden Dengan Kepemilikan SPAL Rumah Tangga

\begin{tabular}{|c|c|c|c|c|c|c|c|}
\hline \multirow{3}{*}{ Pendidikan } & \multicolumn{4}{|c|}{ Kepemilikan SPAL Rumah Tangga } & \multirow{2}{*}{\multicolumn{2}{|c|}{ Jumlah }} & \multirow{3}{*}{ p value } \\
\hline & \multicolumn{2}{|c|}{ Memenuhi syarat } & \multicolumn{2}{|c|}{$\begin{array}{c}\text { Tidak memenuhi } \\
\text { syarat }\end{array}$} & & & \\
\hline & $\mathbf{N}$ & $\%$ & $\mathbf{N}$ & $\%$ & $\mathbf{N}$ & $\%$ & \\
\hline Tinggi ( $\geq$ SMA) & 35 & 71,4 & 14 & 28,6 & 49 & 100 & \multirow{3}{*}{0,000} \\
\hline Rendah (< SMA) & 15 & 19,2 & 63 & 80,8 & 78 & 100 & \\
\hline Total & 50 & 39,4 & 77 & 60,6 & 127 & 100 & \\
\hline
\end{tabular}

Berdasarkan tabel 3. dapat dilihat bahwa dari 127 responden proporsi responden dengan SPAL rumah tangga yang memenuhi syarat kesehatan dengan pendidikan tinggi yaitu 35 ( 71,4 persen) lebih besar dibandingkan dengan proporsi responden dengan SPAL rumah tangga yang memenuhi syarat kesehatan dengan pendidikan rendah yaitu 15 (19,2 persen). Dari hasil uji Chi-Square diperoleh $p$-value 0,000 . Artinya ada hubungan yang bermakna antara pendidikan responden dengan kepemilikan saluran pembuangan air limbah rumah tangga.

Penelitian ini didukung oleh penelitian Dwipayanti \& Utami yang menyimpulkan bahwa pendidikan merupakan salah satu faktor yang mempengaruhi ketersediaan septic tank dan sambungan sewerage system permukiman pinggiran kali Kelurahan Dangin Puri (Dwipayanti \& Utami, 2012).

Menurut Dictionary of Education bahwa pendidikan adalah proses dimana seseorang mengembangkan kemampuan sikap dan bentuk-bentuk tingkah lakulainnya di dalam masyarakat dimana ia hidup. Proses sosial dimana orang dihadapkan pada pengaruh lingkungan terpilih dan terkontrol (khususnya yang datang dari sekolah). Sehingga ia dapat memperolah atau mengalami perubahan kemampuan sosial dan kemampuan individu yang optimal (Ihsan, 2010).

Dalam Notoatmodjo mengungkapkan bahwa pendidikan merupakan salah satu faktor yang mempengaruhi persepsi seseorang untuk lebih mudah menerima pengetahuan baru (Soekidjo Notoatmodjo, 2010).

Dari hasil penelitian yang dilakukan di Desa Belimbing diperoleh bahwa terdapat hubungan yang bermakna antara pendidikan terhadap kepemilikan SPAL rumah tangga, responden yang memiliki SPAL namun tidak memenuhi syarat kesehatan sebanyak (80,8 persen) termasuk dalam kategori pendidikan rendah. Pendidikan rendah yang dimiliki responden berhubungan dengan pola pikir dan perilaku masyarakat. Responden dengan pendidikan rendah akan sulit untuk mengubah pola pikir dan perilakunya sesuai dengan yang kita harapkan. Disamping itu juga, pengetahuan dan pengalaman yang kurang sehingga menyebabkan kurangnya kepedulian khususnya mengenai kesehatan lingkungan. Walaupun telah dilakukan penyuluhan atau pemberian informasi kesehatan kepada masyarakat, namun masih banyak masyarakat yang belum mampu untuk mengaplikasikan informasi yang didapatkan dari penyuluhan tersebut dalam kehidupan sehari-hari. Karakteristik rumah responden yang berbentuk rumah panggung, membuat responden terbiasa membuang air limbah langsung ke pekarangan rumah tanpa menyadari hal apa yang akan ditimbulkan dari kebiasaan tersebut, misalnya dapat merusak tanah permukaan, adanya genangan yang dapat menjadi sarang perindukan nyamuk, menimbulkan bau yang tidak sedap, dan juga dapat mengganggu keindahan. 
Tabel 4. Hubungan Lama Bekerja Responden Dengan Kepemilikan SPAL Rumah Tangga

\begin{tabular}{|c|c|c|c|c|c|c|c|}
\hline \multirow{3}{*}{ Lama Bekerja } & \multicolumn{4}{|c|}{ Kepemilikan SPAL Rumah Tangga } & \multirow{2}{*}{\multicolumn{2}{|c|}{ Jumlah }} & \multirow{3}{*}{ p-value } \\
\hline & \multicolumn{2}{|c|}{ Memenuhi syarat } & \multicolumn{2}{|c|}{$\begin{array}{c}\text { Tidak memenuhi } \\
\text { Syarat }\end{array}$} & & & \\
\hline & $\mathbf{N}$ & $\%$ & $\mathbf{N}$ & $\%$ & $\mathbf{N}$ & $\%$ & \\
\hline Waktu lama & 29 & 56,9 & 22 & 43,1 & 51 & 100 & \multirow{3}{*}{0,002} \\
\hline Waktu tidak lama & 21 & 27,6 & 55 & 72,4 & 76 & 100 & \\
\hline Total & 50 & 39,4 & 77 & 60,6 & 127 & 100 & \\
\hline
\end{tabular}

Berdasarkan tabel 4. dapat dilihat bahwa dari 127 responden proporsi responden dengan SPAL rumah tangga yang memenuhi syarat kesehatan dengan lama bekerja dengan waktu yang lama yaitu 29 (56,9 persen) lebih besar dibandingkan dengan proporsi responden dengan SPAL rumah tangga yang memenuhi syarat kesehatan dengan lama bekerja dengan waktu tidak lama yaitu 21 (27,6 persen). Dari hasil uji Chi-Square diperoleh p-value 0,002 Artinya ada hubungan yang bermakna antara lamanya bekerja responden dengan kepemilikan saluran pembuangan air limbah rumah tangga.

Dari hasil penelitian di Desa Belimbing didapatkan proporsi SPAL rumah tangga yang tidak memenuhi syarat dengan waktu bekerja lama sebanyak 43,1 persen. Hal ini menyebabkan waktu luang untuk beristirahat maupun melakukan pekerjaan rumah lainnya seperti kepedulian terhadap sanitasi lingkungan termasuk SPAL tidak maksimal. Lamanya waktu kerja berkaitan dengan keadaan fisik tubuh pekerja. Pekerjaan fisik yang berat akan mempengaruhi kerja otot, kardiovaskuler, sistem pernapasan, dan lainnya. Jika pekerjaan berlangsung dalam waktu yang lama tanpa istirahat, kemampuan tubuh akan menurun dan dapat menyebabkan kesakitan pada anggota tubuh (Sinaga \& Salmah, 2015).

Dari hasil penelitian yang dilakukan di Desa Belimbing juga diperoleh bahwa terdapat proporsi responden yang memiliki SPAL tidak memenuhi syarat kesehatan dan lama bekerja tidak lama sebesar 72,4 persen seperti petani karet dan juga buruh. Menurut Notoatmodjo, mengungkapkan bahwa pekerjaan mempunyai pengaruh pada pengetahuan seseorang, orang yang menekuni suatu bidang pekerjaan akan memiliki pengetahuan mengenai segala sesuatu yang dikerjakannya (Notoatmodjo, 2003).

Tabel 5. Hubungan Penghasilan Responden Dengan Kepemilikan SPAL Rumah Tangga

\begin{tabular}{|c|c|c|c|c|c|c|c|}
\hline \multirow{3}{*}{ Penghasilan } & \multicolumn{4}{|c|}{ Kepemilikan SPAL Rumah Tangga } & \multirow{2}{*}{\multicolumn{2}{|c|}{ Jumlah }} & \multirow{3}{*}{$p$ value } \\
\hline & \multicolumn{2}{|c|}{ Memenuhi syarat } & \multicolumn{2}{|c|}{$\begin{array}{c}\text { Tidak memenuhi } \\
\text { Syarat }\end{array}$} & & & \\
\hline & $\mathbf{N}$ & $\%$ & $\mathbf{N}$ & $\%$ & $\mathbf{N}$ & $\%$ & \\
\hline Tinggi & 28 & 52,8 & 25 & 47,2 & 53 & 100 & \\
\hline Rendah & 22 & 29,7 & 52 & 70,3 & 74 & 100 & 0,015 \\
\hline Total & $\mathbf{5 0}$ & 39,4 & 77 & 60,6 & 127 & 100 & \\
\hline
\end{tabular}

Berdasarkan tabel 5. dapat dilihat bahwa dari 127 responden proporsi responden dengan SPAL rumah tangga yang memenuhi syarat kesehatan penghasilan tinggi yaitu 28 (52,8 persen) lebih besar dibandingkan dengan proporsi responden dengan SPAL rumah tangga yang memenuhi syarat kesehatan penghasilan rendah yaitu 22 (29,7 persen). Dari hasil uji Chi-Square diperoleh p-value 0,015, artinya ada hubungan yang bermakna antara penghasilan responden dengan kepemilikan 
saluran pembuangan air limbah rumah tangga.

Hasil penelitian ini sejalan dengan penelitian Rahmat \& Safruwandi di Jorong Sentosa Kabupaten Pasaman bahwa ada hubungan bermakna antara penghasilan dengan kepemilikan saluran pembuangan air limbah rumah tangga yang berdasarkan hasil uji statistik diketahui $p$-value 0,011 (Rahmat \& Safruwandi, 2017).

Penghasilan adalah hasil dari mata pencaharian atau sesuatu yang didapatkan sedangkan maksud dari penghasilan total adalah total dari penghasilan sangat mempengaruhi dalam penyediaan sarana pembuangan air limbah karena dengan penghasilan yang relative rendah mungkin untuk pembuatan sarana ini akan sulit dilakukan. Penghasilan yang relatif tinggi diharapkan masyarakat akan mempunyai perhatian yang lebih besar terhadap kesehatan lingkungan termasuk pembuangan air limbah. Faktor ekonomi adalah salah satu penyebab terhambatnya program kesehatan lingkungan dalam mencapai tujuan (Azwar, 2000).

Dari hasil penelitian yang dilakukan di Desa Belimbing diperoleh bahwa terdapat hubungan yang bermakna antara penghasilan terhadap kepemilikan SPAL rumah tangga. Responden yang memiliki SPAL namun tidak memenuhi syarat kesehatan dengan penghasilan rendah masih cukup banyak yaitu sebesar 70,3 persen. Faktor ekonomi merupakan salah satu alat ukur tingkat kesejahteraan suatu masyarakat. Ekonomi juga merupakan indikator penentu perilaku masyarakat dalam pemenuhan kebutuhan sehari - hari termasuk pemanfaatan saluran pembuangan air limbah (Soekijo Notoatmodjo, 2011). Ekonomi yang rendah menyebabkan prioritas utama adalah kebutuhan rumah tangga.

\section{KESIMPULAN DAN SARAN}

Dari hasil penelitian dapat disimpulkan bahwa pengetahuan, pendidikan, lama bekerja dan penghasilan mempunyai peranan penting dalam menciptakan sanitasi lingkungan yang baik khususnya SPAL di Desa Belimbing. Kondisi sanitasi lingkungan terutama SPAL di Desa Belimbing masih harus menjadi perhatian khusus. SPAL yang tidak memenuhi syarat kesehatan menyebabkan mudahnya penyebaran bibit penyakit dan mengganggu keindahan yang berdampak pada rasa nyaman pada lingkungan itu sendiri. Sebagian besar masyarakat masih membuang limbah rumah tangga di halaman sekitar rumah, hal ini didukung pula oleh karakteristik rumah panggung yang mendominasi.

Saran yang dapat diberikan berdasarkan hasil penelitian ini adalah diharapkan petugas kesehatan dapat lebih berperan aktif dalam memberikan motivasi tentang pentingnya memiliki SPAL rumah tangga yang memenuhi syarat kesehatan dan kerjasama lintas sektor dalam melakukan pemicuan terhadap masyarakat setempat, perlu adanya kerjasama yang baik dengan kader kesehatan untuk membentuk kader kesehatan lingkungan dalam mewujudkan program SPAL yang memenuhi syarat kesehatan serta kader kesehatan lingkungan tersebut dapat menjadi penggerak bagi masyarakat lainnya untuk berperilaku hidup bersih dan sehat. 


\section{DAFTAR PUSTAKA}

Azwar, A. (2000). Pengantar Ilmu Kesehatan Lingkungan. Jakarta: Mutiara Sumber Wijaya.

Dinas Kesehatan OKU. (2017). Profil Kesehatan Kabupaten OKU Tahun 2016. Baturaja.

Dwipayanti, Utami. (2012). Faktor Pengaruh Terhadap Ketersediaan Septictank dan Sambungan Sewerage System Permukiman Pinggiran Kali, Kel. Dangin Puri, Denpasar. Jurnal, Universitas Udayana.

Hermawati. (2012). Pengaruh Penyuluhan Kesehatan Terhadap Pengetahuan Keluarga Dalam Pengolahan Limbah Cair Rumah Tangga Di Dusun Bottolampe Kabupaten Barru. Jurnal, STIKES Nani Hasanuddin Makassar. Volume 1 Nomor 1 Tahun 2012.

Ihsan, F. (2010). Dasar-Dasar Kependidikan. Jakarta: Rineka Cipta.

Kementerian Kesehatan. (2014). Profil Kesehatan Indonesia 2014. Kementerian Kesehatan Republik Indonesia (Vol. 51). https://doi.org/10.1037/00223514.51.6.1173

Notoatmodjo, S. (2003). Ilmu Kesehatan Masyarakat. Jakarta: Rineka Cipta.

Notoatmodjo, S. (2010). Promosi Kesehatan dan Perilaku Kesehatan. Jakarta: Rineka Cipta.

Notoatmodjo, S. (2011). Ilmu dan Seni. Jakarta: Rineka Cipta.

Nurhabibah. (2015). Hubungan Perilaku dengan Kondisi Saluran Pembuangan Air Limbah Rumah Tangga di Wilayah Kerja Puskesmas Tapus Kecamatan Padang Gelugur Kabupaten
Pasaman Tahun 2015. Thesis. Universitas Andalas.

Rahmat \& Shafruwandi. (2017). FaktorFaktor yang Berhubungan dengan Kepemilikan SPAL (Saluran Pembuangan Air Limbah) Rumah Tangga, yang Memenuhi Syarat Kesehatan di Jorong Sentosa Kecamatan Padang Gelugur Kabupaten Pasaman Tahun 2017.

Riskesdas. (2013). Laporan Hasil Riset Kesehatan Dasar. Badan Penelitian dan Pengembangan Kesehatan Kementerian Kesehatan 2013.

Sinaga, M \& Salmah, U. (2015). Hubungan Faktor Resiko dengan Terjadinya Nyeri Punggung Bawah (Low Back Pain) pada Tenaga Kerja Bongkar Muat (TKBM) di Pelabuhan Belawan Medan Tahun 2015.

UPTD Puskesmas Lubuk Rukam. (2017). Profil Kesehatan UPTD Puskesmas Lubuk Rukam Tahun 2016. Kabupaten Ogan Komering Ulu. 